Mirjana Drenovak-Ivanović, ${ }^{*} L$ L.D.,

Associate Professor,

Faculty of Law, University of Belgrade,

Jean Monnet Chair in European Environmental Law
ПРЕГЛЕДНИ НАУЧНИ РАД

$10.5937 /$ zrpfn0-28616

UDK: 349.6

502.3(4-672EU:497.11)

Рад примљен: 29.09.2020.

Рад прихваћен: 14.12.2020.

\title{
RIGHTS OF INDIVIDUALS AND OBLIGATIONS OF THE STATE IN PROTECTING AIR QUALITY ${ }^{* *}$
}

\begin{abstract}
The paper analyses the status of international agreements in the field of air protection, aiming to interpret the discord between the adopted legal standards and their application. Having in mind the harmonisation process of Serbian law with the EU law, the author further analyzes the obligations of Member States arising from Directive 2008/50/EC on Ambient Air Quality and Cleaner Air for Europe, the developed practice of the CJEU which embodies elements determining the rights of individuals to initiate a procedure for protecting the right to a healthy environment if states do not adopt an air quality action plan, as well as the measures that domestic courts may prescribe to ensure the implementation of decisions establishing the obligation to implement measures for reduction of emissions above the limit values. The concluding sections analyse the degree of harmonisation of our positive law with the adopted standards and the environmental acquis. Having in mind a substantial number of cases related to air protection in the practice of the Serbian Protector of Citizens (Ombudsman), the analysis of the application of recommendations arising from these cases may suggest the degree of harmonisation of commitments and their application, and serve as an instrument for amending positive law.
\end{abstract}

Keywords: right to clean air, active legal standing of individuals in drafting air quality action plans; state responsibility for transboundary air pollution; CJEU role in direct application of the Directive on Ambient Air Quality and Cleaner Air for Europe.

\footnotetext{
"mirjana.drenovak@ius.bg.ac.rs

${ }^{* *}$ The paper is the result of research activities under Jean Monnet Chair in European Environmental Law, organized with the support of the Erasmus+ Programme of the European Union. The paper was presented at the International Scientific Conference "Responsibility in the Legal and Social Context", organized by the Faculty of Law,University of Nis, on 18 September 2020.
} 


\section{Introduction}

Environmental law regulates legal relations between individuals, the state and individuals, and between states, in matters involving unacceptable environmental quality or a threat of possible disturbance of the reached level of environmental quality. Such issues affect local communities (e.g. construction of a small hydropower plant), residents of one country (e.g. groundwater quality which can only be affected on the territory of that country), several countries (e.g. countries that share the course of the same river), or they can be of a global nature (e.g. climate change or the state of the ozone layer). One of the issues that is both local and global is the issue of air pollution. The elements which are taken into account when establishing the criteria for acceptable air quality are determined by laws and accompanying by-laws. Therefore, in the field of air protection the basis of the legal framework is found in domestic law. However, air is the medium of the environment that illustrates in the best way the interdependence of frameworks governing emissions management and air quality monitoring in different countries. The extent of unsatisfactory air quality impact on human health at the global level is illustrated by the World Health Organization data, stating that 4.2 million people die prematurely every year due to exposure to polluted air (Dechezleprêtre, et al. 2019: 44).

Back in the 1930s, the UK saw the development of a regulatory framework that was supposed to ensure a better control of emissions and improvement of air quality. One of the key bases for further development was the need to keep the existing industrial plants in the local communities, but to provide those communities with cleaner air by introducing new technology. They found the solution in introducing a new method of releasing emissions based on the high stacks concept. High stacks enabled industrial plants and thermal power plants to release emissions at high positions, which provides possibility of mixing emissions with air that carries currents of pollution above the zones that local population is susceptible to. Although the effect had been achieved in the medium term in local communities and air quality was improved, this, however, led to deforestation and significant water pollution in lakes across Germany and Scandinavia, registered throughout the decade from the 1960s to the 1970s (Fisher, et al., 2003: 605). New research shows that emissions from thermal power plants located in the Western Balkans are not restricted to the region, but also greatly affect air quality in the EU (HEAL, 2019). This opened the question of transboundary impact of emissions on air quality and led to the development of a large number of agreements binding on Serbia.

Data underlined by the European Environment Agency (EEA) in its annual reports reveal the impact of emissions on public health in Serbia (EEA, 2017). 
The recently published report of the Environmental Protection Agency (EPA) of Serbia on the state of air quality in 2019 shows that excessive air pollution was recorded in all agglomerations. The Agency assessed the quality of air as that of category III (EPA, 2020)

The presented data, both at the global and national level, raise the following question: which international acts serve as the basis for the responsibility of a state for the air quality on their territory, as well as the responsibility for transboundary emissions? Therefore, the first part of the paper is dedicated to the analysis of ratified international agreements that have a considerable impact on further development of this field of environmental law. Bearing in mind that an obligation of harmonisation with EU law arises from the Stabilization and Association Agreement between the EU and Serbia (2009), in the second part of the paper, we consider the application of the environmental acquis in the field of air protection and recent decisions in infringement procedures, in order to draw conclusions about the rights of individuals which could affect air quality. The question then arises regarding the obligatory activities of the state if the measurement results show that the prescribed limit and tolerance values have been exceeded in one or more pollutants to the extent that the air is excessively polluted. Therefore, the third part of the paper is dedicated to the analysis of domestic legal framework and practice of the Protector of Citizens (Ombudsman) of the Republic of Serbia in order to identify elements that have an impact on the consistent application of the domestic legal framework that guarantees air quality protection.

\section{Status of international agreements in the field of air protection: between ratification and implementation practice}

The field of environmental law that refers to the protection of air quality contains numerous sources. Depending on the object of protection, we can group them into those that dominantly regulate the values of concentrations of certain particles (PM10 and PM 2.5 particles, sulphur dioxide, nitrogen dioxide, etc.), which determine the consequences of air quality on public health. The second group consists of those related to the protection of the ozone layer. The third group consists of sources that regulate the concentration of greenhouse gases and the management of emissions that reinforce climate change. Having in mind the specifics of the issues related to the management of GHG, the paper does not analyse the sources that form the basis of the rights of climate change and the protection of the ozone layer (Drenovak-Ivanović, 2018) The international agreements that Serbia has acceded determine the principles and goals related to the protection of air quality. It is the obligation of each state to harmonise 
the domestic environmental protection policy and air quality management strategies with them.

The Principle 21 of the Stockholm Declaration (1972) established a rule on the responsibility of a state for activities carried out under its jurisdiction or control, which must not harm the environment of another state or areas outside its jurisdiction. In this manner, the exercise of states' sovereign rights is limited if it harms the environment of another state, but also the high seas or areas under special jurisdiction, which includes liability for pollution that may occur due to ship navigation or flight of an aircraft registered on their territory (Sands, 2012: 32). After that, in 1979, the Convention on Long-range Transboundary Air Pollution followed (hereinafter: the Convention), which regulated issues of importance for limiting long-distance air pollution, i.e. in cases where emissions come from sources under the jurisdiction of one state and having harmful consequences which are within the legal jurisdiction of another state. The Convention was ratified by the Act on Ratification of the Convention on Long-range Transboundary Air Pollution. ${ }^{1}$

In international relations, the questions were raised about the procedure and methodology for monitoring the transfer of pollutants in the air, especially about the delimitation of inflows from individual and group sources of pollutants. The program and financing of international cooperation, which would lead to a unified methodology and international cost-sharing of transboundary pollution monitoring, was established by the 1984 Protocol on long-term financing of cooperation programs for monitoring and assessing long-range transboundary air pollution in Europe (EMEP). The Protocol entered into force in 1988 and was ratified by Serbia. ${ }^{2}$ The Environmental Protection Agency is responsible for the implementation of the EMEP.

As the presence of heavy metals and long-lasting organic pollutants from production processes became more evident in industrial emissions, two protocols were signed along with the Convention, which were ratified by Serbia. The first one is the Protocol on Heavy Metals (1998), which entered into force in 2003. ${ }^{3}$ The PHM protocol was adopted in order to reduce emissions of cadmium, lead

1 Act on Ratification of the Convention on Long-range Transboundary Air Pollution, Official Gazette of SFRY-International Agreements, No. 11/86.

2 Act on Ratification of the Protocol to the Convention on Long-range Transboundary Air Pollution on Long-Term Financing of the Cooperation Program for Monitoring and Assessment of Transboundary Air Pollutant Transmission in Europe (EMEP), Official Gazette of SFRY International Agreements. No. 2/87.

3 Act on Ratification of the Protocol on Heavy Metals to the Convention on Long-range Transboundary Air Pollution, Official Gazette of RS International Agreements. No. 1/12. The protocol has been applied in Serbia since June 24, 2012. 
and mercury from industrial processes. However, amendments to the 2012 Protocol, which introduce additional emission control mechanisms that may contain these heavy metals and provide a basis for defining the best available technology (BAT) in such production processes, have not been ratified. The second one is the Protocol on Persistent Organic Pollutants (POPs), adopted in order to eliminate the release of dioxins, furans, polycyclic aromatic hydrocarbons and hexachlorobenzene into the air. The POPs protocol was adopted in 1998 and entered into force in 2003. ${ }^{4}$ In 2009, amendments were adopted to the POPs protocol that introduced restrictions on the emission of additional substances, restrictions on the emission of these gases in waste incinerators and parameters based on which the BAT can be determined in the production processes when these substances are emitted, but these amendments have not been ratified. What's more, neither the Gothenburg Protocol (1999) nor the 2012 amendments establishing maximum national emissions for sulphur oxides, nitrogen oxides, ammonia and volatile organic compounds have been ratified. The application of the Gothenburg Protocol has a significant impact on the production of paints and varnishes, as well as on the development of agriculture, bearing in mind that it envisages measures to reduce emissions of easily volatile organic compounds. ${ }^{5}$

The conducted analysis shows that the Protocols and amendments to the Protocols of the Convention on Long-range Transboundary Air Pollution adopted after 2012 have not been ratified.

\section{EU legislation on Ambient Air Quality and lessons learned from recent CJEU jurisprudence on air quality}

The legal framework that regulates the issues relevant for the protection of air quality with rules that EU Member States have in common are the rules contained in a number of directives. One of the most important directives is the Industrial Emissions Directive 2010/75/EU, which sets emission limit values within the rules on emissions of operators, i.e. introduces a ban on the emission of certain substances. Directive 2010/75/EU prohibits the emission of acid droplets from all installations, and allows the emission of defined substances from

4 Act on Ratification of the Protocol on Long-Term Organic Pollutants with the Convention on Long-range Transboundary Air Pollution, Official Gazette of the RS - International Agreements. No. 1/12. The protocol has been applied in Serbia since June 24, 2012.

5 Protocol on the Reduction of Sulphur Emissions or their Transboundary Fluxes by at least 30 per cent, 1985 and Protocol on Further Reduction of Sulphur Emissions, 1994; Protocol Concerning the Control of Emissions of Nitrogen Oxides or Their Transboundary Fluxes, 1988; Protocol Concerning the Control of Emissions of Volatile Organic Compounds or Their Transboundary Fluxes, 1991to the Convention on Long-Range Transboundary Air Pollution were not adopted by the Republic of Serbia. See: https://unece.org/protocols. 
industrial installations only when they are below the limit values presented in the subsequent Annex to the Directive. ${ }^{6}$ In order for the competent authorities of the Member States to be able to determine whether the conditions of the permits determining the maximum values of emissions of individual elements into the air apply, Member States have an obligation to provide the monitoring of emissions into the air. ${ }^{7}$ Limitation of sulphur emissions into the air was also introduced by EU Directive 2016/802 on the Reduction of sulphur content in certain liquid fuels. ${ }^{8}$ The EU Directive 2016/2284 on the reduction of emissions of certain atmospheric pollutants introduces the possibility to define the emission balance for certain harmful substances at the level of Member State, and thus help reduce emissions in certain areas of industry. ${ }^{9}$

The basics of systemic air quality protection are laid down in Directive 2008/50/ EC on Ambient Air Quality and Cleaner Air for Europe. As a primary responsibility of the Member State for air quality management, the Directive stipulates the obligation of establishing a system to ensure that the levels of sulphur dioxide, PM10, lead and carbon monoxide (in some cases PM2.5) in their zones and agglomerations do not exceed limit values set out in Annex XI to the Directive. The limit values for nitrogen oxides and benzene are set out in the same Annex. ${ }^{10}$ If the levels of air pollutants in certain zones or agglomerations were to exceed the limit values, the Member State would need to draw up an air quality action plan for those zones and agglomerations in order to achieve the relevant limit values or target values. Air quality action plans should specify measures whose application makes the period of exceeding the limit values as short as possible. ${ }^{11}$

In order to understand the reasons for a state to exceed limit values and whether an individual has the right to request the adoption of an air quality action plan

6 Directive 2010/75/EU, Art. 69(1) Annex VIII, Part 2. Such standards exist for various areas of industrial activity, including special rules for combustion, special rules for waste incineration and co-incineration plants, special rules for plants and activities using organic solvents, special rules for plants which produce titanium dioxide, which are regulated by EU Directive 2010/75.

7 Directive 2010/75/EU, Art. 70(2)

8 Directive 2016/802/EU, Preamble and Art. 14.

9 Directive 2016/2284/EU, Art. 6(2) and Annex III Part 2. The model was specifically developed to establish balance as a measure of ammonia emission control in order to reduce emissions from agriculture.

10 Directive 2008/50/EC, Art. 13(1). For nitrogen oxide values, there was a period of 5 years starting from 2010 during which a Member State could request a transitional period;as for exceeding the limit values for benzene, the starting year for the application of thetime frame was set for each Member State.

11 Directive 2008/50/EC, Art. 23(1). 
when the limit values are exceeded and the competent authorities do not adopt such a plan, we further analyse recent examples from the CJEU practice.

In the case of Commission v. Bulgaria (2017), the question was raised whether exceeding limit values of emissions in Bulgaria prescribed by the Directive violates the EU law. ${ }^{12}$ The Commission argued that Bulgaria had systematically and persistently exceeded the limit values, supporting the claim with Bulgaria's annual air quality reports which showed that both daily and annual limit values of PM10 had been exceeded throughout the country for eight consecutive years (with the occasional exception of one of the zones), and that in the same period no downward trend was registered in terms of the number of days of overdraft (paras. 57, 58, 67)(Krämer, 2018). On this basis, the CJEU found that there was a systematic and continuous non-compliance with EU law. (par. 119) The court in the same case did not accept the argument that Bulgaria sought to justify the overdraft, by stating that the efforts to reduce the level of PM10 particles were restrained by the sensitive socio-economic situation of the country, given that PM10 emissions are difficult to reduce since the dominant source of these emissions are heating from individual fireplaces and traffic, and that mostly used fuel during the heating season were wood and coal due to the economic hardship of the Bulgarian population (para. 75). Arguing that Bulgaria had also breached its obligation to draw up an air quality action plan, the CJEU indicated that it was the State's discretion to choose measures which it considered would improve air quality and reduce unwanted emissions below the limit values, but that this discretionary assessment is limited by the obligation of the state that the plan be based on "balance between the goal of reducing the risk of pollution and other engaged public and private interests" (para. 106). In the case of Commission v. Poland (2018), the CJEU pointed to additional criteria for determining the measures to be included in the plan, which must be appropriate and effective (para. 82), and adequately selected to eliminate the case of overdraft as soon as possible (par. 118) ${ }^{13}$ (Kirsten, 2018).

It then became necessary to introduce criteria to assess whether the measures prescribed by the air quality action plan have been adequately chosen. In the case of the Commission v. France (2019), the multiannual excess of nitrogen dioxide emissions by France was justified by the fact that the measures provided for in the air quality action plan to reduce emissions exceeding the limit values

12 Case C-488/15 Commission v Bulgaria [2017]

13 Case C-336/16 Commission v Poland [2018]. In that case, the reasons that led to the conclusion that the envisaged measures were not appropriate were pointed out: , ,... although individual heating of buildings was the main source of PM10 pollution in a large number of zones, the boiler replacement plan could only have an uncertain effect because quality criteria for boilers installed as a replacement for old ones were not prescribed" (para. 86). 
have a limited effect, given the number of public transport users that cannot be increased in the short term, public transport routes that cannot be changed in the short term, and long-term investments that envisage new solutions for population mobility and transformation towards less car use, bearing in mind that traffic was identified as the main source of pollution (para. 29). ${ }^{14}$ France also pointed out that when weighing the interests, it took into account that adopting stricter regulations implying higher fuel tax are not an option, having in mind the sensitivity of public opinion on that issue and the possibility that such measures would lead to new public unrest (para. 31). Arguing the decision that France had breached its obligations under Directive 2008/50/EC, the CJEU pointed to elements relevant for establishing liability for exceeding the limit values (paras. 50-61). First, exceeding the limit values over a long period of time and assessment regarding its further duration form the basis for drawing a conclusion on whether the state is executing its obligations under Art. 23 (1) of Directive 2008/50/EC. Second, in assessing whether the measures envisage by the plan are adequate, one should observe the absolute limit value overdraft. If there is a rise of emissions which should be in accord with limit values, the measures are not adequate. The decreasing trend can also be an indicator whether the measures are adequate: if the reduction is not in line with the extent of the overdraft, the measures do not efficiently lead to a reduction as soon as possible. Third, the adequacy of the measures also depends on the content of the plans, indicating whether the causes that led to the overdraft and the envisaged measures are in accord, as well as whether measures stretch to all sectors relevant for overcoming the problem, and whether they are binding or not (Pedrosa, Vanheusden, 2020). The CJEU also pointed out that the Member State's structural difficulties in implementing emission reduction plans and knowledge if their violation is or is not intentional do not affect the decision on the existence of a violation of EU law (par. 42).

The question further arises: if there is a continuous excess of emissions, and the state fails to adopt air quality action plans, do individuals have the right to legal protection, and what would be the jurisdiction of the domestic court in that case? In the case of Dieter Janecek v. Freistaat Bayern (2008), a German citizen initiated an administrative dispute due to the failure of administrative authorities to adopt an air quality action plan. ${ }^{15}$ In the ruling procedure, the CJEU considered whether, in cases where a Member State does not transpose

14 Case C-636/18 European Commission v French Republic [2019]

15 Case C-237/07 Dieter Janecek v. Freistaat Bayern [2008]. Mr. Janecek filed a lawsuit with the Munich Administrative Court for failure of the City of Munich to adopt an action plan to reduce excessive air pollution, although in 2005 and 2006 there were more than 35 cases of exceeding the particulate matter (PM 10) in the air, bearing in mind that German federal law stipulates that the maximum number of measurements in which an overrun may occur is 35 . 
the Directive provisions on the obligation to draw up an action plan, or it does transpose but does not apply them, there is a possibility that the provisions, envisaged in the Directive 96/63/EC on ambient air quality assessment and management (which was relevant at the time) apply directly? (Doerig, 2014). The CJEU held that the requirements of Directive 96/63/EC prescribing the obligation of Member States to draw up action plans are aimed at protecting human health, and that individuals whose health may be impaired by failure to do so have a subjective right to pursue their adoption and to file a lawsuit with such a request (Kurpus, 2019). Member States are given the discretion to choose the means to achieve the objective; therefore, the discretion must be within the limits of the competence and in accordance with the objective set out in the Directive. In that case, the individual may address the competent national court of the Member State with a request for drawing up an action plan, but not with a request for specific measures (paras 34-42).

If the court of a Member State has an obligation to directly apply the provisions of the Directive in these cases, the question arises whether the court of a Member State, directly applying the provisions of the Directive, along with a decision which determines the responsibility for failing to draw up an action plan and orders its adoption, has an obligation to impose additional obligations which would increase the chances for the adoption of the plan by the competent authorities. We find elements for answering this question in the CJEU's opinions provided in the ClientEarth case (2014). ${ }^{16}$ In 2010, the level of nitrogen dioxide exceeded permitted values in 40 of the 43 zones and agglomerations in the UK, as a result of emissions from traffic and individual furnaces. The NGO ClientEarth has filed a lawsuit in a court of general jurisdiction over the failure of the competent authorities to adopt an action plan for reduction of emissions by 2015. The High Court and the Court of Appeals rejected the lawsuit, considering that these are issues that fall outside their jurisdiction. The UK Supreme Court addressed the CJEU with the preliminary issue regarding measures that should be imposed by a Member State court in the event that the competent authority does not comply with the provisions regarding drawing up the air quality action plan, bearing in mind the obligation under the Directive that the overdraft period must be as short as possible (paras 50-58). The CJEU replied that a court of a Member State must take "any necessary measure such as an order in appropriate terms, so that the authority establishes the plan" (para. 58) (Barrit, 2015). In the practice of EU Member States, we encounter cases where the competent administrative bodies and public authorities do not take the necessary actions for adopting air quality action plans or updating the existing ones, although they are bound by a

16 Case C-404/13 ClientEarth v. The Secretary of State for the Environment, Food and Rural Affairs [2014] 
court decision of a Member State. Therefore, in the case of Deutsche Umwelthilfe (2019), the Higher Administrative Court of Bavaria, Germany, addressed the CJEU with a preliminary issue, asking whether fulfilling the obligation to provide an effective legal remedy in environmental protection, in circumstances which show that, despite the decision of the court ordering the drafting of the plan, it has not been carried out, even after the federal State which was required to fulfil such an obligation was fined, means that the national court may, or even has an obligation, "to impose coercive detention on office holders involved in the exercise of the official authority ... of a German Federal Land in order thereby to enforce the obligation of that Federal Land?"17 (par. 28). The CJEU took the view that " ... in circumstances in which a national authority persistently refuses to comply with a judicial decision enjoining it to perform a clear, precise and unconditional obligation flowing from EU law, in particular from Directive $2008 / 50$, it is incumbent upon the national court having jurisdiction to order the coercive detention of office holders involved in the exercise of official authority where provisions of domestic law contain a legal basis for ordering such detention..." (para. 56).

\section{Application of obligations arising from the international legal framework in Serbia and the practice of the Protector of Citizens}

The conducted analyses of the framework, consisting of international agreements and institutes developed under the auspices of the acquis communautaire, indicate the elements for identifying the basic obligations of the state in the field of air quality protection. In the process of harmonisation of our law with the EU law, we regard the transposition issues of the environmental acquis by observing the process of transposing the directives into domestic law, and we regard the issues related to its implementation by analysing Member States' responses to the challenges of transposing the environmental acquis into the domestic system and practice of CJEU. By regulating issues of importance for air protection, the legislator qualifies the protection and improvement of air quality as "a natural value of general interest that enjoys special protection" (Art. 1 of the Air Protection Act). ${ }^{18}$ The same law prescribes the obligation of competent administrative bodies to perform continuous measurements of air quality and on that basis determine the list of air quality categories. If it is determined that the air quality in a certain agglomeration is excessively polluted, and is assessed as category III air, the competent administrative bodies are obliged to prepare

17 Case C-752/18 Deutsche Umwelthilfe eV v Freistaat Bayern [2019]

18 Art. 1 of the Air Protection Act,Official Gazette of the RS, No. 36/2009 and 10/13. 
an air quality action plan which envisages measures expected to improve air quality (Todić, Dujić, 2020).

The practice of the Protector of Citizens of the Republic of Serbia shows that in previous years there had been a violation of the state's obligations arising from ratified international agreements, which were analysed earlier, and violations of positive law. An example can be found in the procedure regarding control of regularity and legality of the actions of competent authorities regarding the release of emissions caused by fires at the Vinča landfill in 2017, which was introduced by the Protector of Citizens on his own initiative. ${ }^{19}$ The objects of inspection were activities and absence of activities of the Ministry in charge of environmental protection, the Environmental Protection Agency, and the City Institute for Public Health in Belgrade. The Protector of Citizens pointed out the violations and sent an opinion to the Environmental Protection Agency, pointing to the need to implement measures in order to establish and maintain the National Register of Pollution Sources fully and adequately, which would contain data on all pollutant substances reported on, in accordance with the national regulations and signed international protocols. ${ }^{20}$ Such opinion was also expressed in the Recommendation of the Protector of Citizens regarding the control of the regularity and legality of the work of the Ministry in charge of energy and the Environmental Protection Agency regarding the air quality due to emissions coming from the lead smelter in Zajača.

\section{Conclusion}

The conducted analysis shows that Serbia is a signatory to the basic international agreements that set the framework for air quality protection. The development of science and new professional analyses have, over time, indicated an increased impact of certain emissions on human health, which deteriorates public health considerably. In this regard, a number of protocols have made the necessary changes in order to gradually reduce emissions with the largest impact on human health and to introduce obligations that include the control of emissions and gases not envisaged by previous protocols. The conducted analysis shows that the Protocols and amendments to the Protocols of the Convention on Longrange Transboundary Air Pollution adopted after 2012 have not been ratified, and that the rules on reducing emissions that have a considerable impact on human health have not been introduced into our legislation. Bearing in mind that the envisaged rules are mostly part of the environmental acquis, as well as

19 Protector of Citizens, Serbia, Opinion no. 13-22-1952/17, no. 20818 dated June 27, 2018.

20 Recommendation of the Protector of Citizens, letter no. 14-541/12, no. 15408 dated 30 May 2013. 
the intensive harmonisation of Serbian law with the EU law further to signing of the Stabilization and Association Agreement, it is expected that the rules envisaged in unratified Protocols and accompanying amendments will nevertheless become part of the domestic legal framework.

In the CJEU practice, we come across a number of cases initiated by the Commission against Member States regarding the application of directives in the field of air quality protection. The analysis indicates that a Member State cannot give up the application of these directives even when it encounters structural difficulties in the implementation of emission reduction plans, nor when the implementation is made difficult by the country's socio-economic situation. The CJEU pointed out in practice that individuals have the right to initiate proceedings before a Member State court and request the adoption of an air protection action plan if the air pollution exceeds the established limit values and the competent administrative body does not adopt an appropriate air protection action plan. In order to ensure the application of such a decision, the courts of Member States may take any necessary measure, including an order in the appropriate terms. If a national authority persistently refuses to comply with a judicial decision, it is incumbent upon the national court to order, under provisions of domestic law, the coercive detention of office holders involved in the exercise of official authority.

The practice of the Protector of Citizens of the Republic of Serbia indicates the need for further development of positive legal framework for air protection, which should lead to full implementation of the environmental acquis rules in this field, taking into account the views expressed in the practice of CJEU.

\section{References}

Barritt, E. (2015). Standing Up for British Lungs: Effective Judicial Enforcement in Environmental Law-R (on the application of Client Earth) v. Secretary of State for the Environment, Food and Rural Affairs. Review of European, Comparative \& International Environmental Law, 24(3), 368-372.

Dechezleprêtre, A., Rivers, N., Stadler, B. (2019). The economic cost of air pollution: Evidence from Europe. OECD.

Doerig, H. (2014). The German courts and European air quality plans. Journal of environmental law, 26(1), 139-146.

Drenovak-Ivanović, M. (2018). The public's right of access to information on climate change and transposition of the environmental acquis into Serbian legislation. EU and comparative law issues and challenges series (ECLIC), 2, 153-168. 
European Environmental Agency (2017), Coal-fired power plants remain top industrial polluters in Europe, Retrieved 29 Sept. 2020, from https://www.eea. europa.eu/highlights/coal-fired-power-plants-remain.

Environmental Protection Agency (2020). Annual Report on the State of Air Quality in the Republic of Serbia in 2019. Belgrade.

Fisher, E., Lange, B., Scotford, E. (2013).Environmental law: text, cases \& materials. Oxford University Press.

Health and Environment Aliance/HEAL (2019).Chronic coal pollution, Report Summary 2019, Retrieved 29 September 2020 from https://balkangreenenergynews.com/rs/wp-content/uploads/2019/02/Izvještaj-HRONIČNO-ZAGAĐENJE-UGLJEM_Kratki-sadržaj.pdf

Kirsten, W.A.R.D. (2018). ECJ rules that Poland failed to fulfill obligations under Ambient Air Directive. European Journal of Risk Regulation, 9(2), 372-379.

Krämer, L. (2018). 480.000 Dead per Year are Enough: The CJEU Opens a New Way to Better Enforce Air Quality Laws: Commentary on the CJEU Judgment in C-488/15, Commission v. Bulgaria, Judgment of 5 April 2017, ECLI:EU:C: 2017: 267.Journal for European Environmental \& Planning Law, 15(1), 111-121.

Karpus, K. (2019). Using collective redress mechanisms to protect the right to a healthy environment in Poland: An achievable goal in the near future?, in Simon, R., Müllerová, H. (eds.), Efficient Collective Redress Machanisms in Visegrad 4 Countries: an Achievable Target? Praha: Institute of State and Law of the Czech Academy of Science.

Pedrosa, K., Vanheusden, B. (2020). EU Air Pollution Law: Comprehensive but Insufficient. In Research Handbook on EU Environmental Law. Edward Elgar Publishing.

Sands, P. and Peel, J., (2012). Principles of international environmental law. Cambridge University Press.

Todić, D. , Dujić, I., (2020). Kvalitet vazduha" u propisima Republike Srbije i Evropske unije (od nejasne definicije do složenog sistema zaštite vazduha). Zbornik radova pravnog fakulteta u Nišu. Br. 87.37-54.

Zaštitnik građana Republike Srbije (Protector of Citizens): Mišljenje (Opinion) br. 13-22-1952/17, 27 jun 2018, Beograd

Zaštitnik građjana Republike Srbije (Protector of Citizens): Preporuka Zaštitnika građana (Recommendation of the Protector of Citizens), br. 14-541/12, reg.br. 15408, 30 maj 2013, Beograd 
Legal acts

Act on Ratification of the Convention on Long-range Transboundary Air Pollution, Official Gazette of SFRY- International Agreements. No. 11/86.

Act on Ratification of the Protocol to the Convention on Long-range Transboundary Air Pollution on Long-Term Financing of the Cooperation Program for Monitoring and Assessment of Transboundary Air Pollutant Transmission in Europe (EMEP), Official Gazette of SFRY-International Agreements. No. 2/87.

Act on Ratification of the Protocol on Heavy Metals to the Convention on Longrange Transboundary Air Pollution. Official Gazette of RS International Agreements. No. $1 / 12$.

Act on Ratification of the Protocol on Long-Term Organic Pollutants with the Convention on Long-range Transboundary Air Pollution. Official Gazette of the $R S$ - International Agreements. No. 1/12. The protocol is applied in Serbia since June 24, 2012.

Directive 2008/50/EC of the European Parliament and of the Council of 21 May 2008 on ambient air quality and cleaner air for Europe, Consolidated text, OJ L 226, 29.8.2015 and Corrigendum C/2019/2067, OJ L 72, 14.3.2019, p. 141-141.

Directive 2010/75/EU of the European Parliament and of the Council of 24 November 2010 on industrial emissions (integrated pollution prevention and control), OJ L 334, 17.12.2010, p. 17-119.

Directive (EU) 2016/802 of the European Parliament and of the Council of 11 May 2016 relating to a reduction in the sulphur content of certain liquid fuels, OJ L 132, 21.5.2016, p. 58-78.

Directive (EU) 2016/2284 of the European Parliament and of the Council of 14 December 2016 on the reduction of national emissions of certain atmospheric pollutants, amending Directive 2003/35/EC and repealing Directive 2001/81/ EC, OJ L 344, 17.12.2016, p. 1-31.

UNECE Convention on Long-range Transboundary Air Pollution, Geneve, 1979.

UNECE Protocol on Long-term Financing of the Cooperative Programme for Monitoring and Evaluation of the Long-range Transmission of Air Pollutants in Europe (EMEP), Geneva, 1984.

UNECE Protocol on Heavy Metals and its 2012 amended version, Denmark, 1998. UNECE Aarhus Protocol on Persistent Organic Pollutants (POPs), 1998, as amended on 18 December 2009, 1998. 
UNECE Protocol to Abate Acidification, Eutrophication and Ground-level Ozone to the Convention on Long-range Transboundary Air Pollution, as amended on 4 May 2012, 1999.

Zakon o zaštiti vazduha (Air Protection Act), Official Gazette of the RS. No. $36 / 2009$ and $10 / 13$.

Case law

Case C-237/07 Dieter Janecek v. Freistaat Bayern [2008] R.C. I-06221.

Case C-404/13 ClientEarth v. The Secretary of State for the Environment, Food and Rural Affairs [2014] ECLI:EU:C:2014:2382

Case C-488/15 Commission v Bulgaria [2017] EU:C:2017:267.

Case C-336/16 Commission v Poland [2016] ECLI: EU: C: 2018: 94.

Case C-636/18 European Commission v French Republic [2019] ECLI:EU:C:2019:900

Case C-752/18 Deutsche Umwelthilfe eV v Freistaat Bayern [2019] ECLI:EU:C:2019:1114 


\author{
Др Мирјана Дреновак-Ивановић, \\ Ванредни професор Правног факултета, \\ Универзитет у Београду, \\ носилац Жан Моне Катедре за европско еколошко право
}

\title{
ПРАВА ПОЈЕДИНАЦА И ОБАВЕЗЕ ДРЖАВЕ У ЗАШТИТИ КВАЛИТЕТА ВАЗДУХА
}

\begin{abstract}
Резиме
У раду се анализира статус међународних споразума из области заштите ваздуха како би се утвдио степен усаглашености позитивног права са стандардима потврђених међународних споразума. Имајући у виду поступак харминизације права Србије са правом ЕУ, у раду се указује на обавезе држава чланица које произилазе из Директиве 2008/50/E3 о квалитету ваздуха и чистијег ваздуха за Европу. У раде се износе резулати анализе богате пракса Суда правде Европске уније у којој се указује на елементе који одређују право појединца да покрене поступак заштите права на здраву животну средину уколико држава чланица не донесе план заштите квалитета ваздуха, као и мере које домаћи судови могу наложити како би осигурали примену одлуке којом се утврђује обавеза примене мера у циљу смањења емисија које превазилазе граничне вредности. Имајући у виду значајан број предмета у вези са заштитом ваздуха које налазимо у пракси Заштитника грађана, анализа примене препорука које су произашле из тих предмета указује на степен усаглашености преузетих обавеза и њихове примене, каои правце новелирања позитивног права.
\end{abstract}

Кључне речи: право на чист ваздух, активна легитимација појединаца код израде плана квалитета ваздуха, одговорност државе за прекогранично загађење вадуха, улога Суда правде Европске уније у директној примени Директиве о квалитету ваздуха и чистијег ваздуха за Европу. 